\title{
Cercyon Leach, 1817 (Coleoptera: Hydrophilidae: Sphaeridiinae) from Brazil: new species and records
}

\author{
Bruno Clarkson ${ }^{1}$ (), Kleber M. Mise ${ }^{1}$ (1) , Lucia M. Almeida ${ }^{1 *}$ (1) \\ 'Universidade Federal do Paraná (UFPR), Departamento de Zoologia, Laboratório de Sistemática e Bioecologia de Coleoptera, Curitiba, \\ PR, Brasil. \\ urn:lsid:zoobank.org:pub:38C73572-755B-4ABF-B15A-449B83BEE547
}

\section{A R T I C L E I N F O}

Article history:

Received 15/07/2019

Accepted 04/01/2020

Available online 16 March 2020

Associate Editor: Marcela Monné

\section{Keywords:}

Atlantic Rain Forest

Alien species

Amazon forest

Biodiversity

Forensic sciences

Taxonomy

Southern Brazil

Northern Brazil

\begin{abstract}
A B S T R A C T
The study of ca. 280 specimens of Cercyon Leach, 1817 (Hydrophilidae: Sphaeridiinae: Megasternini) deposited in the Coleção Entomológica Pe. J.S. Moure, Universidade Federal do Paraná, Brazil, revealed a new species from Atlantic Rain Forest biome in Paraná State (Southern Brazil) and new records. Cercyon (Cercyon) curi sp. nov. is herein described and illustrated, belonging to the Neotropical C. variegatus species group. Cercyon (Cercyon) nigriceps (Marsham, 1802) is recorded for the first time in Paraná State, and Cercyon (Cercyon) inquinatus Wollaston, 1854 from Amazonas State (Northern Region); these records extend the distributional range of both species in Brazil. Cercyon (Cercyon) praetextatus (Say, 1825) is recorded for the first time from Brazil based on specimens collected in Paraná. Those three species were previously recorded as introduced in South America.
\end{abstract}

\section{Introduction}

The terrestrial hydrophilid genus Cercyon Leach, 1817 is the most speciose one in the subfamily Sphaeridiinae; it currently comprises more than 260 species worldwide. There is a strong contrast between the known diversity of the Neotropical Region (28 described species) and other parts of the world - even the temperate Palaearctic Region is known to host ca. 115 species of the genus (Short and Fikáček, 2011; Fikáček et al., 2015; Arriaga-Varela et al., 2017; Ryndevich and Prokin, 2017; Ryndevich et al., 2017). As highlighted by Arriaga-Varela et al. (2017), the number of described species in the Neotropics seems to be highly underestimated due to the lack of recent taxonomic work. The most comprehensive faunistic study on Neotropical Cercyon is still Sharp's (1882) work although the recently published work of Arriaga-Varela et al. (2017) has clarified the knowledge of the genus in the Greater Antilles. This shortage becomes more evident when we talk about the fauna of Cercyon from Brazil, which currently comprises only three species of which two seem to be native.

\footnotetext{
* Corresponding author

E-mail: lalmeida51@gmail.com (L.M. Almeida)
}

Many species occurring in the Neotropics were introduced from the Old World and are often mistaken as local species (Fikáček, 2009). This is the case of Cercyon (Cercyon) inquinatus Wollaston, 1854, a species of worldwide distribution, recorded as introduced in Rio de Janeiro, Brazil as most of its records are from the Palaearctic Region (Fauvel, 1903; Hansen, 1999; Ryndevich, 2004). Cercyon (Cercyon) variegatus Sharp, 1882 is distributed from USA to Argentina and was recorded from Brazil without precise locality by Smetana (1978). However, the currently known as Cercyon (Cercyon) variegatus is very likely a complex of species since significant morphological variations are found in samples from different areas of the Neotropical Region (Fikáček pers. comm.; Arriaga-Varela et al., 2017) and the records from Brazil may not correspond of the same species originally described from Guatemala and needs confirmation.

Only Cercyon (Cercyon) tantillus Mulsant, 1844 was described from the country but without an accurate locality. Mulsant (1844) described the species based on a specimen sent to M. Dejean by M. Solier who collected "around 'Baya', in Brazil" which possibly refer to somewhere in Bahia State, Northeastern Brazil, but it can also mean any region near a 
bay ('baía' in Portuguese). In his work, Mulsant (1844) highlighted that Cercyon tantillus has a lot of "analogy" with Cercyon centrimaculatum Sturm, 1807. The former species would be distinguishable from the latter mainly by the "lateral rim of the prothorax" which "instead of extending on the sides from the base, stops at the back angles that are not rounded". Cercyon centrimaculatum is currently a senior synonym of Cercyon (Cercyon) nigriceps (Marsham, 1802) (Stephens, 1839; Gemminger and Von Harold, 1868) and the taxonomic status of Cercyon tantillus must be reviewed with the proper examination of the type specimen in future work.

Cercyon species have predominantly terrestrial habits and are frequently associated with decaying plant and animal matter, as well as feces (Hansen, 1991). Therefore, it commonly occurs on carcasses being potentially important to forensic science (Mise et al. in prep.). The study of ca. 280 specimens of Cercyon deposited in the Coleção Entomológica Pe. J.S. Moure, Universidade Federal do Paraná revealed a new species from the State of Paraná, Southern Brazil, and new records. Cercyon (Cercyon) curi sp. nov. (Figs. 1-3) is herein described and illustrated. In addition, the worldwide distributed species Cercyon (Cercyon) nigriceps (Marsham, 1802) and Cercyon (Cercyon) inquinatus Wollaston, 1854 are recorded from Paraná and Amazonas States respectively enlarging their distributional range in the country (Fig. 4). Cercyon (Cercyon) praetextatus (Say, 1825), a widely distributed species in North and Central America, is recorded for the first time in Brazil. All three species were previously recorded as introduced in South America (Fauvel, 1903; d' Orchymont, 1939; Fikáček, 2009).

\section{Materials and methods}

All specimens were examined using a Zeiss Discovery V20 binocular stereomicroscope $(150 \times)$. Measurements were taken using a Wild M5-31261 binocular stereomicroscope (100x) with the aid of an ocular micrometer. The measures presented for the holotype followed largely those proposed by Oliva (1989) for the genus Berosus Leach, 1817. Abdomen and male genitalia were dissected and cleared in $10 \%$ $\mathrm{KOH}$ at $40^{\circ} \mathrm{C}$ for about 10 minutes, stored in a microvial pinned with the specimen. The description and measurements of the new species were based on the holotype.

Photographs were taken from holotype (Figs. 1A-C) and paratype specimens (Figs. 2A-D and 3A-D). Each figure was composed of 15 to 25 photographs taken with a Leica M205C binocular microscope (100x) with an attached camera and aligned, stacked and combined using the Leica LAS EX software. The terms applied for morphological features followed Komarek (2004) and Arriaga-Varela et al. (2017) with some terminology adapted from Lawrence et al. (2011). Labels of the examined material are arranged in sequence from top to bottom, the data for each label are within double quotes (" "), a slash (/) separates the rows and double slashes (//) separate the labels.

The presented map was made using SimpleMappr (Shorthouse, 2010), edited in the software Adobe Illustrator vCS6. Geotagging was done based on the information in the labels of each examined specimens and available in the literature, the coordinates are approximate and may not correspond to the exact spot where the specimens were collected.

Examined material is deposited in the following collections: Coleção Entomológica Pe. J.S. Moure, Universidade Federal do Paraná, Curitiba, Paraná, Brazil (DZUP, L. M. Almeida); Setor de Entomologia da Coleção Zoológica, Universidade Federal de Mato Grosso, Cuiabá, Mato Grosso, Brazil (CEMT, F. Z. Vaz-de-Mello); Museu Nacional, Universidade Federal do Rio de Janeiro, Rio de Janeiro, Brazil (MNRJ, M. L. Monné); Museu de Zoologia da Universidade de São Paulo, São Paulo, Brazil (MZSP, S. A. Casari); National Museum, Prague, Czech Republic (NMPC, M. Fikáček);
Division of Entomology, University of Kansas, Natural History Museum, Lawrence, USA (SEMC, A. Short);

Checklist of the Cercyon Leach occurring in Brazil

1. Cercyon (Cercyon) curi sp. nov.: Brazil (PR).

2. Cercyon (Cercyon) inquinatus Wollaston, 1854: worldwide, introduced to Brazil (AM, RJ).

3. Cercyon (Cercyon) nigriceps (Marsham, 1802): worldwide, introduced to Brazil (PA, PR).

4. Cercyon (Cercyon) praetextatus (Say, 1825): widespread in North and Central America, from Canada to Costa Rica and Caribbean, introduced in Argentina and Brazil (PR).

5. Cercyon (Cercyon) tantillus Mulsant, 1844: Brazil (BA?).

6. Cercyon(Cercyon) variegatus Sharp, 1882: from USA to Argentina, including Brazil (?).

\section{Taxonomic treatment}

\section{Cercyon Leach, 1817}

Cercyon Leach, 1817: 95. - Type species: Dermestes melanocephalus Linnaeus (designated by Thomson, 1859: 19).

Diagnosis. Small to medium sized beetles (1.0-6.0 $\mathrm{mm}$ in length). Body elongate oval in dorsal view, convex in lateral view (Figs. 1A and C). Clypeus narrowing anteriorly, slightly convex, truncate to slightly arcuate apically. Antennae with nine antennomeres; compact club (Figs. 1A and B, 2A). Maxillar palpomere 2, swollen (Fig. 2A). Prothorax with conspicuous antennal groove not reaching pronotal margin (Fig. 2B); prosternum tectiform, carinate medially, medial part not demarcated from lateral parts (Fig. 2B). Elytra with 10 distinct longitudinal rows of punctures, forming fine striae (Fig. 1A). Mesoventrite with posteromedial elevation forming an elongated oval plate, narrowing anteriorly and posteriorly, pointed or rounded posteriorly, not closely fused with metaventral elevation (touching anterior margin of metaventrite, in one short point)(Fig. 2D). Metaventrite with pentagonal median elevation, not projected between mesocoxae (Fig. 2D). Middle and hind legs with flattened tibiae and tarsus with tarsomere 1 longer than 2 (Fig. 1B). Abdomen with five ventrites; ventrite 1 carinate medially (Fig. 3A).

\section{Cercyon (Cercyon) curi sp. nov.}

(Figs. 1A-C, 2A-D and 3A-F)

Type locality. Brazil, Guarapuava Municipality, Paraná State, Est. Águas Santa Clara

Type Material. Holotype (male): “Guarapuava - Paraná/ Est. Águas Sta. Clara/ BRAZIL 30. I. 1987/ Lev. Ent. PROFAUPAR/ LÂMPADA”(DZUP); Paratypes (230 exs.): BRAZIL: Paraná: Antonina: "ANTONINA-PR/ Reserva Spitanduva/ BRASIL 25. IV. 1987/ Lev. Ent. PROFAUPAR/ LÂMPADA" (8 exs.: DZUP); same data, different dates, all specimens deposited in DZUP: “30. XI. 1986” (1 ex.); “01. XII. 1986” (1 ex.); “03. XII. 1986” (1 ex.); “20. IV. 1987” (1 ex.); “31. I. 1987” (1 ex.); “30. III. 1987” (1 ex.); Colombo: “COLOMBO -PR/ EMBRAPA BR476 km20/ BRASIL 01. III. 1987/ Lev. Ent. PROFAUPAR/ LÂMPADA” (2 exs.: DZUP); same data, different date: “30. I. 1987” (1 ex.: DZUP); Curitiba: “Curitiba-PR (BR)/ Centro Politécnico/ Bandeja/ 07/X/2005/ Mise, K. M.” (1 ex.: DZUP); same data, different dates, all specimens deposited in DZUP: "13/X/2005" (1 ex.); “24/XI/2005” (1 ex.); “30/XI/2005” (1 ex.); “31/I/2006” (1 ex.); Fênix: "FÊNIX - PARANÁ/ Reserva Est - ITCF/ BRASIL 27. III. 1987/ Lev. Ent. PROFAUPAR/ LÂMPADA" (101 exs.: DZUP; 5 exs.: MNRJ; 5 exs.: MZSP; 5 exs.: NMPC; 5 exs.: SEMC; 5 exs.: CEMT); same data, different dates, all specimens deposited in DZUP: “28.III.1987" (16 exs.); “29. II.1987” (1 ex.); Guarapuava: Same data as Holotype (5 exs.: DZUP); same data, 

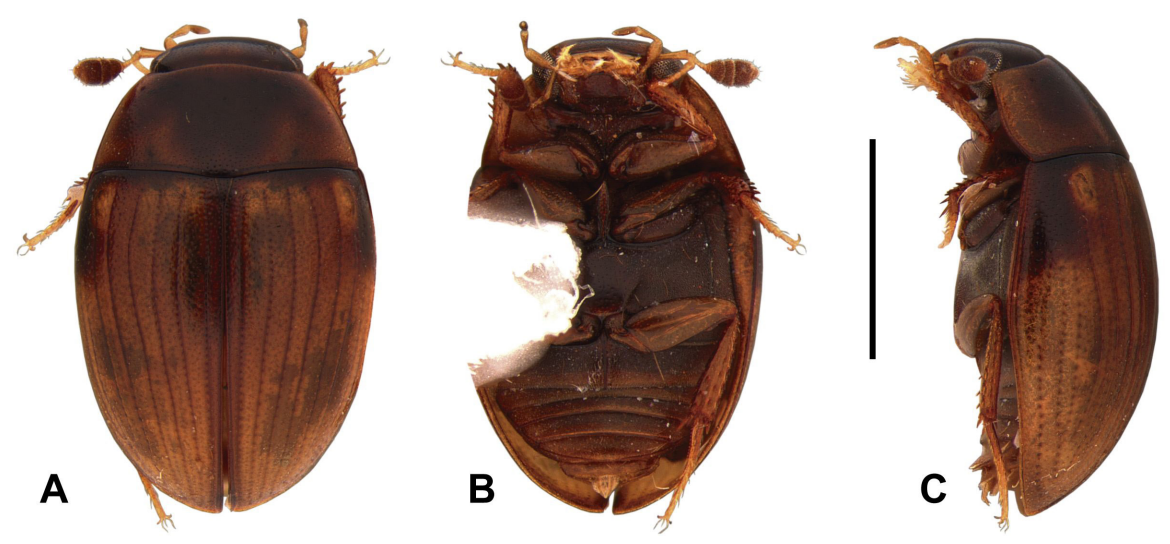

Figure 1. Cercyon curi sp. nov. Habitus, (A) dorsal view, (B) ventral view, (C) lateral view, scale = $1.0 \mathrm{~mm}$.

different dates, all specimens deposited in DZUP: “29.XI.1986” (4 exs.); “01.XII.1986” (2 exs.); “02.XII.1986” (2 exs.); “30.XII.1986” (1 ex.); “01. I.1987” (8 exs.); “25. II.1987” (1 ex.); Jundiaí do Sul: "JUNDIAÍ DO SUL - PR/ Fazenda Monte Verde/ BRASIL 30. XI. 1986/ Lev. Ent. PROFAUPAR/ LÂMPADA" (1 ex.: DZUP); same data, different dates, all specimens deposited in DZUP: “03. XII. 1986” (3 exs.); “30. XII. 1986” (3 exs.); “01. I. 1987” (5 exs.); “02. I. 1987” (2 exs.); “29. I. 1987” (1 ex.); “30. I. 1987” (2 exs.); “27. II. 1987” (1 ex.); “01. III. 1987” (1 ex.); “26. IV. 1987" (12 exs.); “27. IV. 1987” (8 exs.); “25. V. 1987” (1 ex.); São José dos Pinhais: "S. JOSÉ PINHAS - PR/ Ser. do Mar BR277 Km54/ BRASIL 29. VII. 1987/ Lev. Ent. PROFAUPAR/ LÂMPADA" (1 ex.: DZUP); Telêmaco Borba: "TELÊMACO BORBA - PR/ Res. Samuel Klabin/ BRASIL 28. II. 1987/ Lev. Ent. PROFAUPAR/ LÂMPADA" (2 exs.: DZUP).

Diagnosis. Small to medium sized species $(2.00-2.55 \mathrm{~mm}$ in length); dorsal surface of head dark brown to black, posterocentral area on frons often lighter, brown in front of eyes and in the anterior margins of clypeus (Fig. 2A); pronotum with two lateral and one central large fused black spots, diffuse, brown to pale brown at posterior and lateral portions; elytra pale brown to yellow, darker along sutural area and in the apical margin; with moderate sized black spots on anterolateral portions, black at basal margins, pale in the humeral humps (Fig. 1A and C); prosternal medial ridge thickened anteriad; mesoventral plate (Fig. 2D) narrowly elongate, ca. 5.9× as long as wide, pointed posteriorly; metaventrite (Fig. 2D) without femoral lines, with narrow raised pentagonal area, $1.1 \times$ as long as wide; first abdominal ventrite not projecting posteriorly in both sexes (Fig. 3A); apex of fifth abdominal ventrite slightly acuminate apex, weakly bulged in both sexes (Fig. 3A). Sternite 9 (Fig. 3B) asymmetrical basally, with median process narrow and short, widely acuminate at apex, without subapical setae; phallobase (Figs. 3C-E) almost twice as long as parameres, slightly asymmetrical at base; parameres in dorsal view narrow, inner margins somewhat concave, in ventral view inner margins are extended inwardly, somewhat convex; apex acuminate and narrowly rounded, turned inwardly, without setae (Figs. 3C-E); median lobe (Figs. 3D and F) abruptly constrict at apical fourth, acuminate at apex, without subapical spines; sigmoid shaped in lateral view (Figs. 3C).

Description. Holotype male.

Size and form. Total length $2.18 \mathrm{~mm}$; maximum width $1.38 \mathrm{~mm}$; maximum width of the head $0.70 \mathrm{~mm}$; elytral length $1.64 \mathrm{~mm}$; maximum width of the pronotum $1.20 \mathrm{~mm}$; maximum height $1.00 \mathrm{~mm}$. Body oval, moderately convex (Figs. 1A-C).

Coloration. Dorsal surface of head dark brown to black, posterocentral area on frons often lighter; posterolateral portion of clypeus (in front of eyes), and anterior margins brown (Fig. 2A). Pronotum with two lateral and one central large fused black spots, almost reaching anterior margin, with posterior and lateral surfaces brown to pale brown; limits of spots diffuse (Figs. 1A and C). Elytra pale brown to yellow, slightly darker on elytral disc (on interstriae 1-6) from elytral base until ca. of apical quarter, conspicuously darker along sutural area and in the apical margin; with moderate sized black spots on anterolateral portions (anterior quarter); black at anterior margins; pale in the humeral humps (Fig. 1A and C). Ventral surface of head brown; antennomeres 1 to 6 light brown to yellow, distal club brown; labial and maxillary palps light brown (Figs. 1B, 2A and B). Ventral face of thorax and abdomen brown to dark brown. Legs brown, pro and mesotarsus lighter (Fig. 1B).

Head. Labrum membranous, nearly completely concealed under clypeus, only with narrowly exposed sinuate anterior margin (Figs. 2A and B). Clypeus with rather coarse and dense punctuation, distance between punctures ca. 1.0-2.0 the width of one puncture, shallowly impressed, consisting of crescent-shaped setiferous punctures intermixed with dense, crescent-shaped non-setiferous punctures, about the same sized of setiferous; interstices without microsculpture. Anterior clypeal margin with a narrow bead (Figs. 2A and B). Frontoclypeal suture inconspicuous (Fig. 2A). Frons with punctation similar to that on clypeus, punctures sparser on sides; interstices without microsculpture. Eyes rather small; interocular distance about $5 \times$ the width of one eye in dorsal view (Figs. 2A and B). Mentum subtrapezoid, widest at posterior fourth, about $1.5 \times$ wider than long, $1.8 \times$ wider at posterior margin than anterior margin, concave in anterior half, with a shallow transverse impression anteromesally; surface glabrous, punctures rather coarse and shallow, interstices slightly rugose. Antenna with 9 antennomeres, scapus about $2 \times$ as long as antennomeres 2-6 combined; antennal club broad, pubescent and about the same length as scapus, antennomere 9 barely acuminate at apex (Figs. 1B, 2A).

Prothorax. Pronotum transverse, widest at base $2.1-2.2 \times$ wider than long; $1.4-1.5 \times$ wider at base than between anterior angles, $1.7 \times$ wider than head including eyes, as convex as the elytra in lateral view (Fig. 1A). Punctation on pronotal disc homogeneously distributed on surface, moderately dense and shallow, consisting of crescent-shaped punctures intermixed with slightly smaller and rather transverse punctures; punctures slightly feebler on sides; distance between punctures ca. $1.0-3.0 \times$ the width of one puncture; punctures with decumbent setae scattered on pronotal disc (Fig. 2C). Prosternum strongly tectiform medially, medial ridge thickened anteriad, forming a small rounded to slightly pointed process. Antennal grooves distinct, with curved external margins, well-marked anteriorly (Fig. 2B).

Pterothorax. Scutellar shield $1.4 \times$ as long as wide, sparsely punctured (Fig. 2C). Elytral surface glabrous, except for scattered small systematic punctures (trichobothria) set with very short decumbent setae. Elytron with 10 punctural series, well-marked, forming longitudinal striae; series 

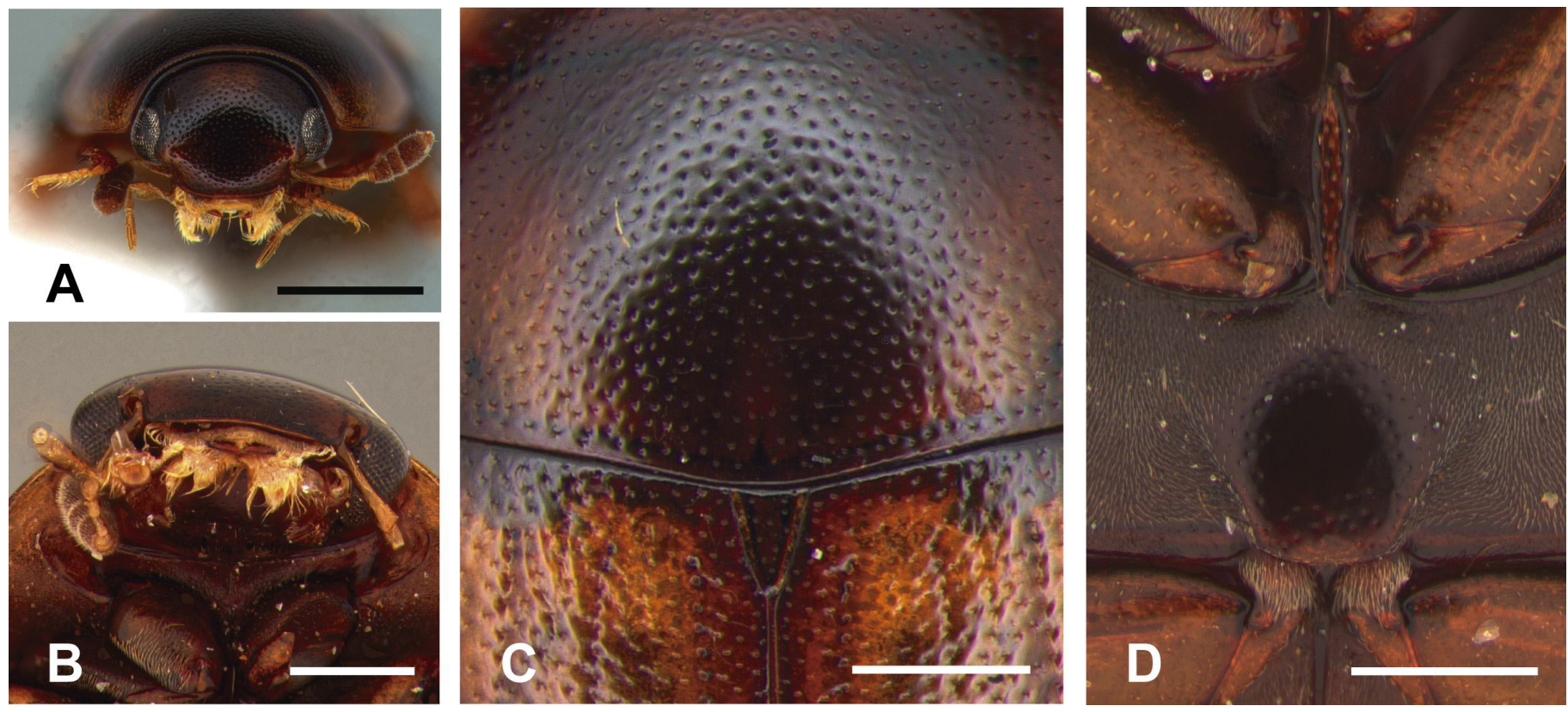

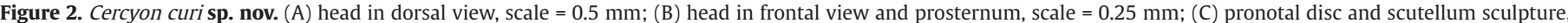
scale $=0.2 \mathrm{~mm}$; (D) mesoventral plate and metaventral elevation, scale $=0.25 \mathrm{~mm}$.

6-10 not reaching elytral base; series 10 shortened posteriorly, reaching half of the elytral length, lying parallel to elytral margin (Figs. 1A and C). Serial punctures of the same size in the series 1-6; slightly larger in the series 7-10; intervals weakly convex (Figs. 1A and C); interval punctation composed by crescent-shaped punctures intermixed with denser, slightly smaller and rather transverse punctures in all intervals. Humeral hump slightly prominent (Fig. 1A). Elytral epipleura wide (Fig. 1B) Mesoventral plate (Fig. 2D) narrowly elongate, ca. 5.9× as long as wide, widest in at midlength, strongly narrowed in the anterior and posterior apices, which are pointed, posterior tip sharply acuminate, overlapping over anterior portion of metaventrite; surface with a few sparse coarse punctures. Metaventrite (Fig. 2D) with narrow raised pentagonal area, $1.1 \times$ longer than wide, glabrous, weakly and sparsely punctuate, punctures with fine setae at least along margins of the elevation; bare elevated area not reaching anterior margin of metaventrite; punctures absent at two slightly elongate areas in the center; femoral lines absent; lateral parts of metaventrite densely covered by short pubescence.

Legs. Meso and metafemora with sparse rather shallow punctures, interstices with very weak microsculpture on ventral face, consisting of longitudinal lines, this microsculpturation is more evident along anterior margins of femora; tibial grooves distinct. Tibiae with rather small lateral spines. Metatibiae moderately narrow and elongate, straight, $0.3 \times$ as long as elytra, $5 \times$ as long as wide. Metatarsus ca. as long a metatibia, with short rather stout setae ventrally. Last tarsomere of each tarsus with long setae ventrally.

Abdomen. First abdominal ventrite about as long as the second and third ventrites together, with distinct median longitudinal carina narrowing posteriad, not projecting posteriorly in both sexes (Fig. 3A); fifth ventrite with slightly acuminate apex, weakly bulged in both sexes (Fig. 3A).

Male genitalia. Sternite 9 (Fig. 3B) asymmetrical basally, median process narrow and short, ca. as long as half of lateral struts, slightly widening apically, widely acuminate at apex, without subapical setae. Phallobase (Figs. 3C-E) narrow and long, ca. 2.9× longer than wide, almost twice as long as parameres, widely rounded at basal margin, slightly asymmetrical at base, manubrium indistinct. Outer margins of parameres very weakly concave, almost subparallel sided; parameres in dorsal face narrow, inner margins continuously narrowing apically until the distal thirds of parameres, which the apex bent inwardly, giving a concave shape, in ventral face parameres extended inwardly, inner margins contiguous and subparallel until the distal thirds of parameres, which the outline bends outwards, convex anteriorly, merging with dorsal portion subapically, without setae; apex acuminate and narrowly rounded, turned inwardly, without setae (Figs. 3C-E). Median lobe (Figs. 3D and F) widest at midlength, slightly narrowing towards base, abruptly constrict at apical fourth, widely narrowing into an acuminate, widely pointed apex, without subapical spines; sigmoid shaped in lateral view (Fig. 3C); gonopore moderately large, subapical; basal portion with dorsal plate narrow and simply bifid basally.

Variation. The examined specimens vary in body size (from $2.00 \mathrm{~mm}$ to $2.55 \mathrm{~mm}$ in length). The general dorsal coloration varies in non-teneral specimens: dark areas can be dark-brown to black while light areas can be pale-yellow to light-brown or "testaceous"; frons is completely dark or slightly lighter in the posterocentral area (as in Fig. 2A); dark area in pronotum can be more or less developed; in paler specimens the elytra are completely yellow except base, sutural interval, and the anterolateral spots; in darker specimens the whole anterior part of elytra, from base until ca. of apical quarter, and the elytral suture are distinctly darkened, with pale areas maintained in humeral area and at sides of scutellar shield; elytral longitudinal striae can have the same coloration of the elytral surface, can be slightly darker than elytral surface and slightly distinct by coloration (as in Fig. 1A) or dark brown to black, distinct from elytral surface by coloration. There is not evident sexual dimorphism in the external morphology.

Etymology. The specific epithet curi is a Tupi-Guarani aboriginal word that means "pine tree". It is a reference to the characteristic conifer tree Araucaria angustifolia (Bertol.) Kuntze, 1898 preponderant in the mixed ombrophilous Atlantic rain forest and typical of the Paraná State. The name is used as a noun in apposition.

Distribution. Brazil, Paraná State: Antonina, Colombo, Curitiba, Fênix, Guarapuava, Jundiaí do Sul, São José dos Pinhais and Telêmaco Borba municipalities (Fig. 4). 

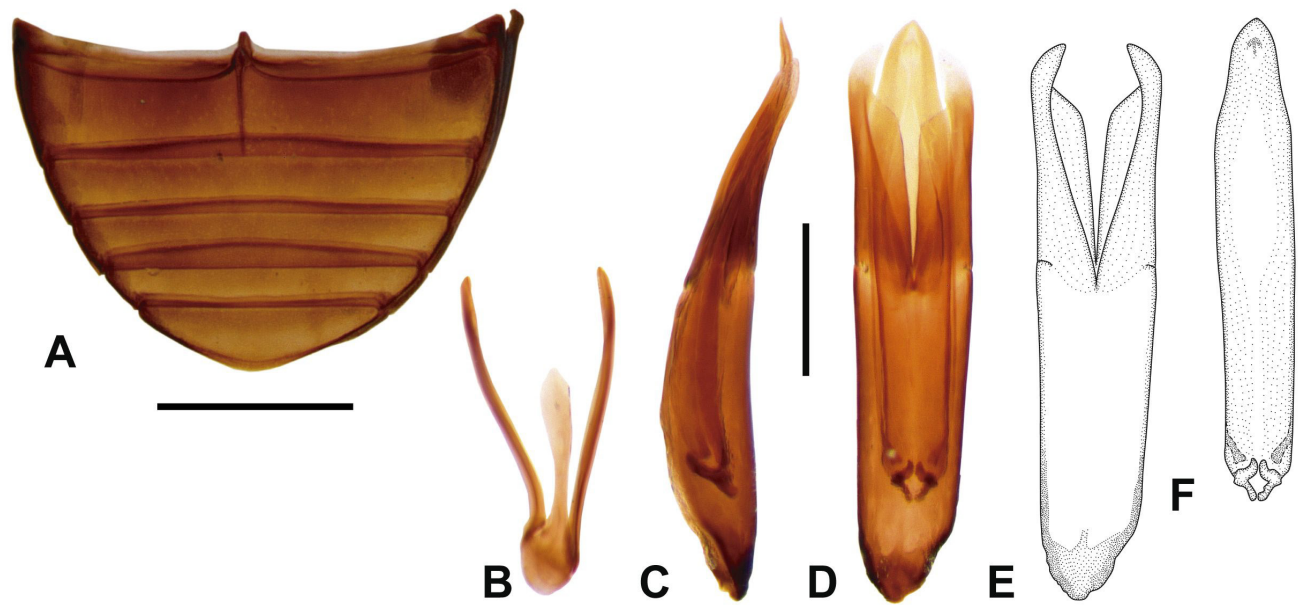

Figure 3. Cercyon curi sp. nov. Abdomem, (A) abdominal ventrites, scale = $0.5 \mathrm{~mm}$; terminalia (B-F), (B) sternite 9; aedeagus (C-F), (C) lateral view; (D) dorsal view; (E) Phallobase and parameres in dorsal view; $(\mathrm{F})$ median lobe in dorsal view, scale $=0.2 \mathrm{~mm}$.

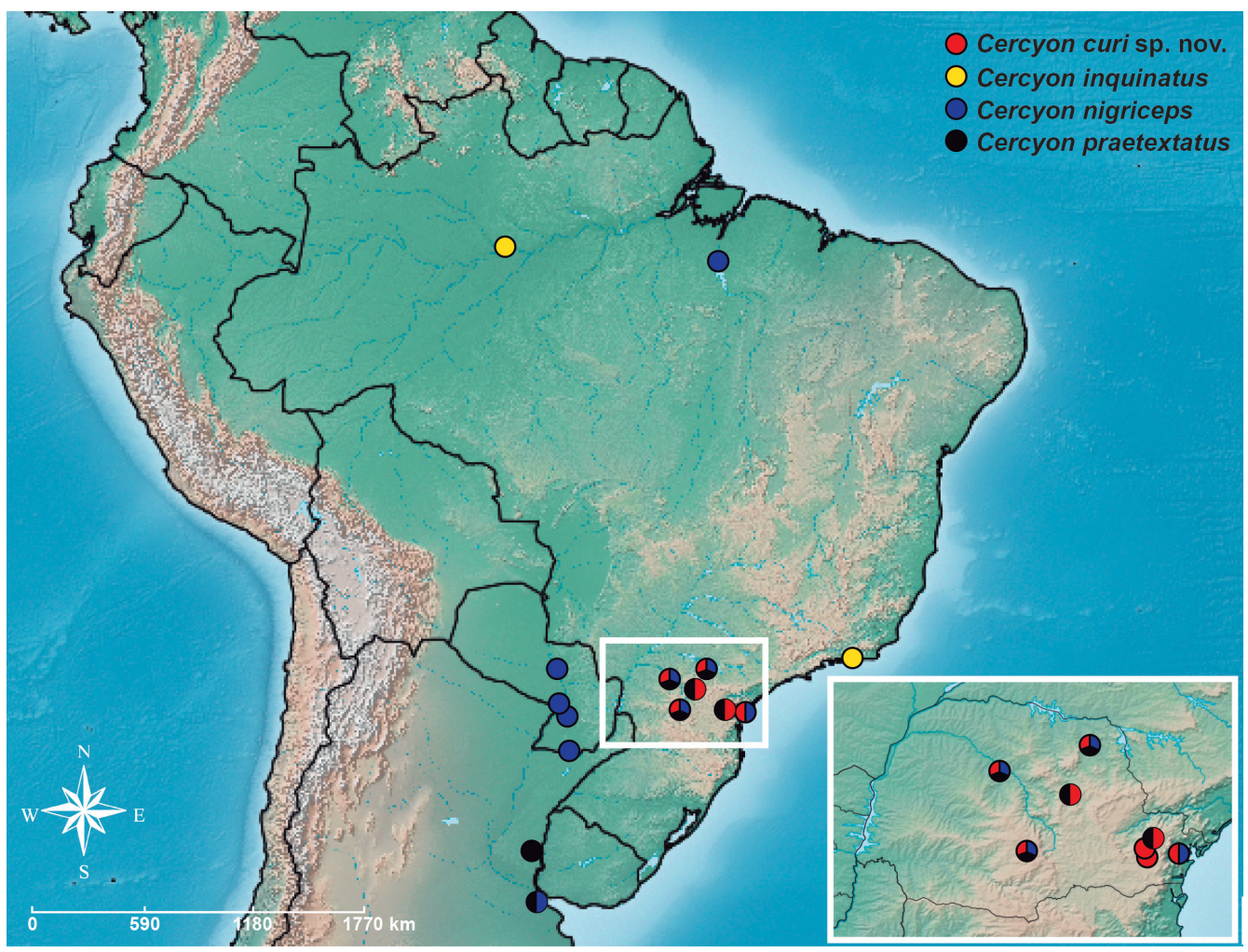

Figure 4. Map with the known distribution of Cercyon curi sp. nov., Cercyon inquinatus Wollaston, 1854, Cercyon nigriceps (Marsham, 1802) and Cercyon (Cercyon) praetextatus (Say, 1825) in South America based on d'Orchymont (1939), Fikáček (2009) and the current work. White square highlights the region of Paraná State where most part of the examined specimens is from.

Bionomics. Most of the examined specimens were collected using light as indicated in their labels with the word "LÂMPADA" which means "lamp" in Portuguese but five specimens from Curitiba municipality were collected in pig carcass in a controlled forensic experiment of entomological succession during putrefaction and butyric fermentation stages.

Discussion. The new species belongs to the subgenus Cercyon (s. str.) as defined by Smetana (1978) that is characterized by having the middle portion of prosternum simply elevated to form longitudinal median keel (tectiform), not differentiated laterally from antennal grooves of prothorax which are therefore completely open medially (Fig. 2B); elevation of mesoventrite narrowed posteriorly, contacting the elevated middle portion of metaventrite at a single point (Fig. 2D); and the pronotum and elytra together convex in lateral view, forming continuous outline (Fig. 1C). Inside Cercyon (s. str.) the new species seems to be closely related with Cercyon insularis Chevrolat, 1863 and C. variegatus Sharp, 1882 based on similarities in the external morphology - as coloration pale with distinctive dark pattern (Figs. 1A-C); dorsal surface glabrous, without evident microsculpture; elytral epipleura wide (Fig. 1B); elevated middle portion of mesoventrite narrow and elongate, its posterior part contacting metaventrite; and metaventrite without femoral lines (Fig. 2D) - and in the general shape of the aedeagus - with long and narrow phallobase widely rounded at base with manubrium indistinct (Figs. 3C-E). 
Based on these characteristics, Cercyon curisp. nov. should belong to the species complex corresponding to the $C$. variegatus group of Smetana (1978), distributed from the southern USA to Argentina. The new species can be distinguished from $C$. insularis and $C$. variegatus mainly by characteristics of the male genitalia (Figs. 3B-F, see Arriaga-Varela et al., 2017: Fig. 4 for detailed illustration of $C$. insularis and $C$. variegatus) which the sternite 9 (Fig. 3B) is asymmetrical basally, with median process short, ca. as long as half of lateral struts, widely acuminate at apex, without subapical setae (symmetric basally, with median process longer than half of lateral struts, rounded apically, with a pair of subapical setae in $C$. insularis and $C$. variegatus); phallobase is slightly broader (ca. $2.9 \times$ longer than wide) than in $C$. variegatus (ca. $3.8 \times$ longer than wide) and distinctly broader than in $C$. insularis (ca. $5 \times$ longer than wide); phallobase is only slightly asymmetrical at base in $C$. curi sp. nov. (the asymmetry at the base in $C$. insularis and $C$. variegatus is more evident); parameres narrower in dorsal face, with the inner margins continuously narrowing apicad until the distal thirds, the apex bent inwardly giving a concave shape to inner outline (inner margins of parameres in dorsal face is continuously narrowing apicad until the subapical portion, and the apex is pointed, abruptly bent inwardly in $C$. variegatus; the parameres are subparallel-sized and widely rounded at apex, slightly turned outwards distally in C. insularis); in ventral face the parameres are extended inwardly with the inner margins contiguous and subparallel until the distal thirds of parameres, which the outline bends outwards, giving a convex aspect anteriorly, without setae (parameres are not extended in this way in C. insularis; in $C$. variegatus the parameres are also extended inwardly but the inner margins are not contiguous, tapering outwards until the distal thirds of parameres, which shortly bends outwards, giving an angulate aspect anteriorly, anterior margin of the projected portion with setae); as in $C$. insularis, the new species does not have setae at paramere apex (with setae at apex in $C$. variegatus); the median lobe in C. curisp. nov. (Figs. 3D and F) is constricted at apical fourth, widely narrowing into an acuminate widely pointed apex (median lobe is subparallel throughout and simply pointed at apex in $C$. insularis and is also subparallel throughout, and acuminate at apex but has a small flank on each side).

Besides $C$. curi sp. nov., $C$. insularis and $C$. variegatus the species recorded from Suriname as "Cercyon rishwani” by Makhan (2004) also belongs to the $C$. variegatus complex based on color pattern of the pronotum and the general shape of the aedeagus, but a more detailed comparison is impossible based on the description and illustrations provided. "Cercyon rishwani Makhan, 2004" is moreover considered a nomen nudum (Short and Hebauer, 2006; Arriaga-Varela et al., 2017).

\section{Cercyon (Cercyon) inquinatus Wollaston, 1854}

Cercyon inquinatum Wollaston, 1854: 103.

Cercyon inquinitum Wollaston; Wollaston, 1864: 94.

= Cercyon (s.str.) knischi Müller, 1924: 77 (synonymized by d'Orchymont, 1940: 45).

= Cercyon gebieni Knisch, 1925: 202 (synonymized by Smetana, 1979: 961)

= Cercyon (Clinocercyon) faeceus Balfour-Browne, 1954: 230 (synonymized by Smetana, 1979: 961).

= Cercyon austriacus Vogt, 1974: 190 (synonymized by Hofmann \& Flechtner, 2003: 225)

= Cercyon rhombicus Jia, 1995: 18 (synonymized by Ryndevich, 2004: 9)

For complete synonymy see Smetana (1979), Hansen (1999) and Ryndevich (2004).
Material examined: BRAZIL: Amazonas: Manaus: "Brasil - AM, Manaus/ Reserva Adolpho Ducke/ 11/VII/2008/ K. M. Mise (Leg.)// Coleta manual/ Isca carcaça suína// Cercyon (Cercyon)/ inquinatus/ Wollaston, 1854/ Clarkson det. 2018" (1 female: DZUP).

Discussion. This is an adventive species currently distributed in all zoogeographical regions, which was described based on specimens from Madeira Island in Portugal and your synonyms: Cercyon (Cercyon) knischi Müller, 1924, were described based on specimens from Croatia (Dalmatia, Zadar) and Italy (Trieste, San Giovanni and Sicily); Cercyon (Cercyon) gebieni Knisch, 1925 from Indonesia (Java); Cercyon (Clinocercyon) faeceus Balfour-Browne, 1954 from Mascarene Islands and Mauritius; Cercyon austriacus Vogt, 1974 from Austria; and Cercyon rhombicus Jia, 1995 from China (Guangdong). There is no assurance on its primary provenance (Hansen, 1999). In Neotropical Region the species was solely recorded in Rio de Janeiro State, Brazil until up to date (Fauvel, 1903). The species is herein recorded for the first time in Amazon forest area of Amazonia State (Northern Brazil) enlarging our knowledge on the distribution of this species since in the New World the species is recorded only in U.S.A. (Smetana, 1978) besides Brazil (Fig. 4). The examined specimen is a female and was recognized based on external characters such as the small size (body length $2.0-2.7 \mathrm{~mm}$ ); body shape rather strongly convex and broadly oval; dark-brown dorsal coloration; dorsal surface with extremely fine, sparse, decumbent pubescence; ninth elytral stria present as distinct row of coarse punctures; and lateral portions of metaventrite with fine and rather sparse, shallow, pit-like punctures. The easiest way to identify the species is with the examination of the aedeagus. For more detailed information on the morphology and illustrations of the species see Smetana (1979).

Bionomics. The examined specimen was collected in pig carcass in a controlled forensic experiment of entomological succession during the putrefaction stage (Mise et al., 2010). The species is known as terrestrial and are usually found inhabiting all kinds of decaying organic matter as rotting debris on sea beaches, debris at the edges of ponds, rotting leaf litter and decaying fruits, cave guano, etc. (Smetana, 1979; Ryndevich, 2007).

\section{Cercyon (Cercyon) nigriceps (Marsham, 1802)}

Dermestes nigriceps Marsham, 1802: 72.

Cercyon nigriceps (Stephens, 1829): 151.

= Dermestes atricapillus Marsham, 1802: 72 (synonymized by Gemminger and Von Harold, 1868: 498; precedence of $C$. nigriceps over $C$. atricapillus determined by Stephens, 1839: 97, see also Hansen, 1999: 284).

= Sphaeridium centrimaculatum Sturm, 1807: 23 (synonymized by Gemminger and Von Harold, 1868: 498).

= Cercyon striatus Sharp, 1882: 108 (synonymized by Fikä̈cek, 2009: 354).

= Cercyon panamensis Hansen, 1999: 286 (replacement name of C. striatus Sharp; synonymized by Fikal̈cek, 2009: 354).

For complete synonymy see Smetana (1978), Hansen (1999) and Ryndevich and Hebauer (2010).

Material examined: BRAZIL: Paraná: Antonina: "ANTONINA -PR/ Reserva Spitanduva/ BRASIL 31.I.1987/ Lev. Ent. PROFAUPAR/ LÂMPADA" (1 male: DZUP); same data, different date: "27.II.1987" (1 male: DZUP); Fênix: "FÊNIX - PARANÁ/ Reserva Est - ITCF/ BRASIL 30.XI.1986/ Lev. Ent. PROFAUPAR/ LÂMPADA” (1 ex.: DZUP); same data, different dates, all specimens deposited in DZUP: "27.I.1987" (3 exs.); “27. III. 1987” (3 exs.); “28. III. 1987” (1 ex.); “25. IV. 1987” (2 exs.); Guarapuava: “GUARAPUAVA - PARANÁ/ Est. Água Sta.Clara/ BRASIL 28.I.1987/ Lev. Ent. PROFAUPAR/ LÂMPADA" (2 males and 1 unsexed 
specimen: DZUP); same data, different dates, all specimens deposited in DZUP: “31.XII. 1986” (1 male); “02. II. 1986” (1 female); Jundiaí do Sul: “JUNDIAÍ DO SUL - PR/ Fazenda Monte Verde/ BRASIL 30.XII.1986/ Lev. Ent. PROFAUPAR/ LÂMPADA" (6 exs.: DZUP); same data, different dates, all specimens deposited in DZUP: “01.I.1987” (1 ex.); “30.I.1987” (1 ex.).

Discussion. This is an adventive species currently distributed in all biogeographical regions, which probably is native from the Oriental Region (Smetana, 1978; Hansen, 1999). In Neotropical Region, the species is recorded from Costa Rica, Panama, Cayman Islands, Greater and Lesser Antilles, Brazil, Paraguay, and Argentina. In Brazil, it is recorded from Pará State, north of the country (Fikáček, 2009; Arriaga-Varela et al., 2017). The species is herein recorded for the first time in Atlantic rain forest area of Paraná State Southern Brazil and shows a wide range distribution in the State (Fig. 4). The new distribution records are compatible with the known wide distribution of the species in South America (Fig. 4). The species is easily recognizable by the very small size (body length 1.0-2.1 mm), metaventrite with complete femoral lines and the conspicuous male genitalia. For more detailed information on the morphology and illustrations of the species see Smetana (1978) and Arriaga-Varela et al. (2017).

Bionomics. All examined specimens were collected at light as indicated in their labels with the word "LÂMPADA" which means "lamp" in Portuguese but this species is known as terrestrial and are usually found inhabiting dung of various herbivorous mammals (e. g. cow and horse) as well as other kinds of decaying organic matter (rotting plant debris, compost piles, carrion), also recorded from nests of birds and small rodents (Smetana, 1978; Hansen, 1987; Ryndevich, 2007; Fikáček, 2009; Arriaga-Varela et al., 2017).

\section{Cercyon (Cercyon) praetextatus (Say, 1825)}

Sphaeridium praetextatum Say, 1825: 190.

Cercyon praetextatum(Say): Melsheimer, 1853: 37.

For complete synonymy see Smetana (1978) and Hansen (1999).

Material examined: BRAZIL: Paraná: Colombo: “COLOMBO -PR/ EMBRAPA BR476 km20/ BRASIL 30. I. 1987/Lev. Ent. PROFAUPAR/ LÂMPADA" (1 ex.: DZUP); Guarapuava: “Guarapuava - Paraná/ Est. Águas Sta. Clara/ BRAZIL 02. XII. 1986/ Lev. Ent. PROFAUPAR/ LÂMPADA” (2 exs.: DZUP); same data, different dates, all specimens deposited in DZUP: “03. XII. 1986” (1 ex.); “31.XII.1986” (1 ex.); “27.I.1987” (1 ex.); “28.I.1987” (1 ex.); “31. I.1987” (1 ex.); “26.II.1987” (1 ex.); “27.III.1987” (1 ex.); Fênix: "FÊNIX - PARANÁ/ Reserva Est - ITCF/ BRASIL 27.I.1987/ Lev. Ent. PROFAUPAR/ LÂMPADA" (1 ex.: DZUP); same data, different date: "29.III.1987" (1 ex.: DZUP); Jundiaí do Sul: "JUNDIAÍ DO SUL - PR/ Fazenda Monte Verde/ BRASIL 30. XI. 1986/ Lev. Ent. PROFAUPAR/ LÂMPADA" (3 ex.: DZUP); same data, different dates, all specimens deposited in DZUP: “01. I. 1987” (2 exs.); “28. II. 1987” (1 ex.); 31.III. 1987” (1 ex.); Telêmaco Borba: "TELÊMACO BORBA - PR/ Res. Samuel Klabin/ BRASIL 31. XII. 1986/ Lev. Ent. PROFAUPAR/ LÂMPADA” (2 exs.: DZUP); same data, different dates, all specimens deposited in DZUP: "27. I. 1987" (1 ex.); “01. III. 1987” (1 exs.); “25. II. 1987” (1 exs.).

Discussion. This species is widely distributed in North and Central America - with occurrence in Canada, USA, Mexico, Guatemala, Costa Rica, Cayman Islands, Cuba, Dominican Republic and Jamaica (Smetana, 1978; Hansen, 1999; Arriaga-Varela et al., 2017). Cercyon praetextatus was recorded as introduced in Argentina by d'Orchymont (1939) based on specimens collected around Buenos Aires (Tigre). Fikácek (2009) confirmed the occurrence and the hypothesis that the species is introduced in Argentina based on specimens from Entre Rios Province (Colón). The author pointed out that the species seems likely to be native in the northern part of the Neotropical Region. Cercyon praetextatus is herein recorded for the very first time in Brazil as a widely distributed species in Paraná State. According to this distribution, seems likely the species was introduced in the "Southern Cone" of Latin America but we cannot rule out the possibility of a natural wide distribution in the New World, since Sphaeridiinae have been neglected in South American biodiversity studies and the missing of records of Cercyon throughout the continent may be consequence of the lacking of collecting and taxonomic works focused in the group.

The species is easily recognizable by the moderate small size (body length 2.4-4.1 mm); dorsal coloration with head dark-brown to black, pronotum dark-brown to black (in all examined specimens) sometimes with sharply defined yellowish to reddish areas at anterolateral corners or at lateral margins (Smetana, 1978; Arriaga-Varela et al., 2017), elytra dark-brown to black with large sharply-defined yellowish to reddish-yellow lateroapical area reaching about apical fourth, laterally reaching elytral base in lateralmost interval, yellow spot not extended to humeral area basally; medial ridge of prosternum anteriorly forming a small rounded to slightly pointed process; mesoventral plate wide (ca. $3 \times$ as long as wide); and the conspicuous male genitalia. For more detailed information on the morphology and illustrations of the species see Smetana (1978) and Arriaga-Varela et al. (2017).

Bionomics. All the examined specimens were collected with light traps but according to with Smetana (1978) the species seems to prefer primarily wet environments (such as edges of lakes and streams, marshes, wet deciduous forests, etc.) and can be found on many kinds of organic debris, leaf-litter, decomposing plant remnants, carrion, and dung.

\section{Acknowledgments}

We would like to thank our colleges of the Laboratório de Sistemática e Bioecologia de Coleoptera for encouraging and supporting our work. We are indebted to Guilherme Morikoshi for sorting material as part of his undergraduate project in UFPR. We also would like to thank Dr. M. Fikáček and Dr. S. K. Ryndevich for providing valuable improvements in reviewing the manuscript. Financial support was provided by Programa Nacional de Pós-Doutorado (CAPES, Brazil) granted by PPG em Entomologia (UFPR) to B. Clarkson and by researcher fellowship granted by CNPq (308992/2017-2) to L.M. Almeida.

\section{Conflicts of interest}

The authors declare no conflicts of interest.

\section{References}

Arriaga-Varela, E., Seidel, M., Deler-Hernández, A., Senderov, V., Fikáček, M., 2017. A review of the Cercyon Leach (Coleoptera, Hydrophilidae, Sphaeridiinae) of the Greater Antilles. ZooKeys 681, 39-93. https:// doi.org/10.3897/zookeys.681.12522.

Balfour-Browne, J., 1954. Descriptions of four new species of Hydrophilidae from Mauritius and Reunion. Maurit. Inst. Bull. 3, 227-233.

Fauvel, A., 1903. Faune analytique des Coléoptères de la NouvelleCalédonie. Rev. Entomologie 22, 203-379.

Fikáček, M., 2009. Occurrence of introduced species of the genus Cercyon (Coleoptera: Hydrophilidae) in the Neotropical Region. Rev. Soc. Entomol. Argent. 68 (3-4), 351-357.

Fikáček, M., Angus, R. B., Gentili, E., Jia, F., Minoshima, Y. N., Prokin, A., Przewoźny, M., Ryndevich, S. K., 2015. Family Hydrophilidae. In: Löbl, I., Löbl, D. (Eds.), Catalogue Palaearctic Coleoptera: HydrophiloideaStaphilinoidea. Vol. 2/1. Koninklijke Brill NV, Leiden-Boston, 1702 pp. 
Gemminger, M., Von Harold, E., 1868. Catalogus Coleopterorum hucusque descriptorum synonymicus et systematicus. Monachii. Tom II, 425-978.

Hansen, M., 1987. The Hydrophiloidea (Coleoptera) of Fennoscandia and Denmark. In: Brill, E.J. (Ed.), Fauna Entomologica Scandinavia 18. Scandinavian Science Press Ltd., Leiden Copenhagen, 245 pp.

Hansen, M., 1991. The hydrophiloid beetles: phylogeny, classification and a revision of the genera (Coleoptera, Hydrophiloidea). Biologiske Skrifter 40, 1-367.

Hansen, M., 1999. World Catalogue of Insects 2: Hydrophiloidea (s. str.) (Coleoptera). Apollo Books, Amsterdam, 416 p.

Hofmann, G., Flechtner, G., 2003. Cercyon austriacus Vogt, 1974 ist synonym zu Cercyon inquinatus Wollaston, 1854 (Coleoptera, Hydrophilidae). Entomol. Blatter 98, 225-229.

Jia, F., Wu, W., Pu, Z., 1995. Studies on Cercyon of China (Coleoptera: hydrophilidae). J. Sun Yatsen Univ. (Suppl.2), 124-130. [in chinese].

Komarek, A., 2004. Taxonomic revision of Anacaena Thomson, 1859. I. Afrotropical Species (Coleoptera: hydrophilidae). Koleopterol. Rundsch. 74, 303-349.

Knisch, A., 1925. Neue Palpicornier aus dem aquatorialen Orient (Coleoptera: hydrophilidae). Treubia 6, 199-206.

Lawrence, J. F., Slipinski, A., Seago, A. E., Thayer, M. K., Newton, A. F., Marvaldi, A. E., 2011. Phylogeny of the Coleoptera based on morphological characters of adults and larvae. Ann. Zool. Warsz. 61, 1-217. https://doi.org/10.3161/000345411X576725.

Leach, W. E., 1817. The Zoological Miscellany. Vol. 3. R.P. Nodder, London. 151 pp., pl. 121-150.

Makhan, D., 2004. Hydrochidae of the World, Dryopidae and Hydrophilidae (Coleoptera). Calodema 2, 11-26.

Marsham, T., 1802. Entomologia Britannica, Sistens Insecta Britanniae Indigena, Secundum Methodum Linnaeanam Disposita. Tomus. 1. Coleoptera. Wilks \& Taylor, London. 548 pp. https://doi.org/10.5962/ bhl.title.65388.

Melsheimer, F. E., 1853. Catalogue of the Described Coleoptera of the United States. Smithsonian Institution, Washington.

Mise, K. M., Souza, A. S. B., Campos, C. M., Keppler, R. L. F., Almeida, L. M., 2010. Coleoptera associated with pig carcass exposed in a forest reserve, Manaus, Amazonas, Brazil. Biota Neotrop. 10 (1), 321-324. Available in: http://www.biotaneotropica.org.br/v10n1/ en/abstract?inventory+bn03110012010 (accessed 12 July 2019).

Müller, J., 1924. Nuovi coleotteri paleartici. Boll. Soc. Entomol. Ital. $56,68-80$.

Mulsant, E., 1844. Description de quelques Palpicornes inédits. Ann. Soc. Agric. Lyon 7, 372-382.

Oliva, A., 1989. El genero "Berosus" (Coleoptera: Hydrophilidae) en America del sur. Rev. Mus. Argent. Cienc. Nat., 6 (4), 57-236.

d' Orchymont, A., 1939. Notes sur quelques Palpicornia de la Republique Argentine. Rev. Soc. Entomol. Argent. 10, 253-264.

d' Orchymont, A., 1940. Synonymie d'un Cercyon italien. Boll. Soc. Entomol. Ital. 72, 45.

Ryndevich, S. K., 2004. Review of species of the genus Cercyon Leach, 1817 of Russia and adjacent regions. I. Subgenus Cercyon (s. str.) Leach, 1817. Cercyon lateralis-group (Coleoptera: Hydrophilidae). Ann. Univ. Mariae Curie-Skłodowska, C Biol. 59, 29-41.

Ryndevich, S. K., 2007. Ecological classification on the basis of ecological preferences for the genus Cercyon Leach, 1817 (Coleoptera: Hydrophilidae) of the Palaearctic Region. In: Voronezh, V.G.U.(Ed.),
Problemy Vodnoy Entomologii Rossii Isopredel'nykh Stran: Mater. III Vserossiyskogo Simpoziuma po Amfibioticheskim i Vodnym Nasekomym Rossii. Publishing and Printing Center of Voronezh State University, Voronezh, pp. 281-284.

Ryndevich, S. K., Hebauer, F., 2010. Review of species of the genus Cercyon Leach, 1817 of Russia and adjacent regions. V. Subgenus Cercyon (s. str.) Leach, 1817. Cercyon nigriceps-group (Coleoptera: hydrophilidae). Zoosyst. Ross. 19 (2), 330-340.

Ryndevich, S. K., Jia, F., Fikáček, M., 2017. A review of the Asian species of the Cercyon unipunctatus group (Coleoptera: Hydrophilidae: Sphaeridiinae). Acta Entomol. Mus. Natl. Pragae 57 (2), 535-576.

Ryndevich, S. K., Prokin, A. A., 2017. Two new species of Cercyon (Clinocercyon) from Russian Far East (Coleoptera: hydrophilidae). Zootaxa 4300 (1), 125-134.

Sharp, D., 1882. Insecta: Coleoptera. Vol. 1. Part 2 (Haliplidae, Dytiscidae, Gyrinidae, Hydro- philidae, Heteroceridae, Parnidae, Georissidae, Cyathoceridae, Staphylinidae). In: Godman, F.C., Salvin, O. (Eds.), Biologia Centrali-Americana. Vol. 16. Taylor \& Francis, London.

Say, T. 1825. Descriptions of new species of Coleopterous Insects inhabiting the United States. J. Acad. Nat. Sci. Phila. 5 (1), 160-204.

Short, A. E. Z., Fikáček, M., 2011. World catalogue of the Hydrophiloidea (Coleoptera): additions and corrections II (2006-2010). Acta Entomol. Mus. Natl. Pragae 51, 83-122.

Short, A. E. Z., Hebauer, F., 2006. World Catalogue of Hydrophiloidea: additions and corrections, 1 (1999-2005) (Coleoptera). Koleopterol. Rundsch. 76, 315-359.

Shorthouse, D.P., 2010. SimpleMappr: an Online Tool To Produce Publication-Quality Point Maps. Available in: https://www. simplemappr.net (accessed 12 July 2019).

Smetana, A., 1978. Revision of the subfamily Sphaeridiinae of America north of Mexico (Coleoptera: hydrophilidae). Mem. Entomol. Soc. Can. 105, 1-292.

Smetana, A., 1979. Revision of the subfamily Sphaeridiinae of America north of Mexico (Coleoptera: Hydrophilidae). Supplementum 1. Can. Entomol. 111, 959-966.

Stephens, J. F., 1829. Illustrations of British Entomology: Mandibulata. Vol. 2. Baldwin and Cradock, London, 200 pp.

Stephens, J.F., 1839. A Manual of British Coleoptera, or Beetles. Longman, Orme Brown, Green and Longmans, London, 443 pp.

Sturm, J., 1807. Deutschlands Fauna in Abbildungen nach der Natur mit Beschreibungen. V. Abteilung. Die Insecten. Vol. 2. J. Sturm, Nürnberg, 1-4 + 1-219., pl. 21-52. (Also under title: Deutschlands Insecten. Käfer.)

Thomson, C. G., 1859. Skandinaviens Coleoptera. Vol. 1. Berlingska Boktryckeriet, Lund, $290 \mathrm{pp}$.

Vogt, H., 1974. Cercyon-Studien II. Entomol. Blatter Biol. Systematik Kafer 70, 190-192.

Wollaston, T. V., 1854. Insecta Maderensia: Being an Account of the Insects of the Islands of the Madeiran Group. John Van Voorst, London, $634 \mathrm{pp}$.

Wollaston T.V. 1864. Catalogue of the Coleopterous Insects of the Canaries in the Collection of the British Museum. Order of the Trustees, London, 648 pp. 